\title{
Obituaries
}

Obituaries should be submitted by email to Laura Pacey at I.pacey@nature.com.

All submitted obituaries should be 350 words maximum in length (apart from obituaries for past presidents of the BDA where the length should be $700-800$ words).

Content of the obituary is down to the individual author, and the approval of the family should be given for the obituary prior to submission to the $B D J$.

\section{DENYS HALLEY GOOSE}

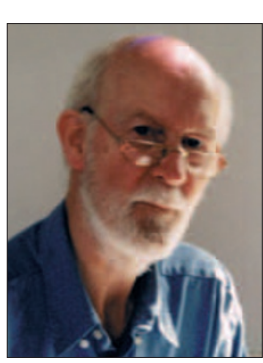

1923-2013.

Denys Goose died in April 2013 after a short illness at the age of 90 .

He was the Director of Postgraduate Dentistry at Liverpool University

when he retired in 1982 .

After attending King Edward's School in Birmingham he went on to study dentistry at Birmingham University, following the earlier example of his sister Muriel Davis. ${ }^{1}$

Denys carried out his national service in 1946 as part of the Army Dental Corps, serving mainly in Egypt. He decided to join the School Dental Service and was appointed Chief Dental Officer for Northamptonshire in the late 1950s. During this period he determined to pursue research into the causes of dental disease.

He was appointed as Lecturer in Preventive Dentistry at Liverpool University in 1963 and moved to Chester with his wife, Janet, a museum curator, and their three children Paul, Barbara and Leslie. After becoming a senior lecturer Denys published extensively on his subject, producing over 100 research papers, and was responsible for authoring and coauthoring a series of books for Pergamon Press. These included Principles of preventive dentistry (1964) and Human dentofacial growth (1982). His reputation grew internationally and he travelled to a variety of countries, such as America, Scandinavia, Italy and Russia to lecture and further his research. In 1973 he became a reader of the university.

Denys actively pursued a number of outside interests, was a committed
Quaker, and a member of the Campaign to Protect Rural England, as well as having a lifelong love of cricket. Following retirement, which he enjoyed with Janet, he held influential positions in a number of environmental and transport groups in both Chester and Shrewsbury, where he moved in 1989. He leaves a son, daughter and two grandsons.

The family of Denys Goose

1. Davis J E C. Muriel E. H. Davis, obituary. Br Dent J 2013; 214: 321.

\section{E. RANKINE CRERAR}

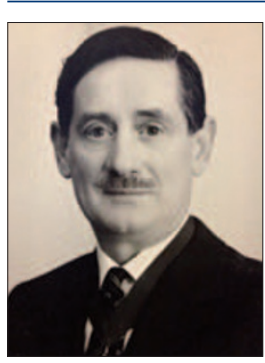

1918-2013

Rankine, never

known to us as

Edward, died on 7

June in Edinburgh, after a short illness. With his passing the profession has lost one of the few

dentists who had experience of dentistry prior to the inception of the NHS and the transformation of practice consequent to the arrival of 'free dentistry'.

Rankine was born in Paisley on 5 October 1918, in the closing days of WWl, the son of a dentist who had started practice in 1900. After early education at Glasgow High School, he entered Glasgow Dental Hospital and School. On the outbreak of WW2, he left to join the Tank Corps, but soon was returned to complete his dental studies and graduated in 1942. Returning to the services, now in the Royal Army Dental Corps, he was posted to India. When he returned home, he succeeded his father in the Paisley practice.

He soon took an active interest in BDA affairs, which were now enmeshed with the new regulatory authority, something of a political football, and the butt of music-hall jokes. Rankine brought great negotiating skill and cautious advice to all the Association committees of which he was a member, and as Chairman, always sought settlements in the best interest of dentists, with fairness to those who ultimately paid for our services - the patients.

Having been appointed Scottish Secretary of the Association, he was called to take on the duties of National Secretary at short notice. This entailed a long commuting journey and much time away from home. He retired in 1986.

Such a full professional career might leave ordinary men only with time for rest but for Rankine his family was always his first priority. His marriage to Betty and their children, Anne and Scott, held pride of place. After Betty's death, he married Elspeth, and he added the role of step-father to Marie, Sandy and Marj.

Fishing holidays in the North of Scotland had been a feature of childhood life that endured to the end; as did his enthusiasm for golf, gardening and bridge. Moving home from Paisley to Strathaven introduced him to rural life, farming affairs and the delights of attending the local auction market. After Elspeth's death in 2008 he continued to live on his own, welcoming many visitors.

We can but acknowledge his great contribution to making our Association what it has become and express our sympathy to all his family, children, and grandchildren, of whom two, Vicky and Alastair (McGill), continue the family tradition in practising dentistry. I, and my family, thought he would go on forever.

Brian J. Murray 